DOI: $10.15290 /$ pnib.2020.08

ks. Wojciech Rogowski

\title{
Zatroskanie Arcybiskupa Edwarda Kisiela o świętość katechetów
}

Zmarły w 1993 roku Arcybiskup Edward Kisiel ${ }^{1}$ zapisał się we wspomnieniach kapłanów i wiernych jako ten, który „najbardziej troszczył się o katechizację dzieci i młodzieży"(abp St. Szymecki). Potwierdzają to również protokoły z konferencji katechetycznych odbywanych na terenie (archi)diecezji białostockiej, w których brał udział. Wypowiadając się o swej posłudze kapłańskiej mówił: „Przez wszystkie lata kapłańskie najbardziej absorbowała mnie dziedzina katechizacji. Temu zagadnieniu poświęcałem najwięcej uwagi".

W 1976 roku ks. Edward Kisiel otrzymał nominację na biskupa tytularnego Limaty i administratora apostolskiego Archidiecezji w Białymstoku. Jego hasłem biskupim stały się słowa: Evangelizare misit me (Posłał mnie, abym głosił Ewangelię) $)^{2}$. Jako biskup - pierwszy katecheta w diecezji - żywo interesował się sprawami katechetycznymi, zwłaszcza katechetami i katechizowanymi, których otaczał ojcowską troską. Ogromną wagę przywiązywał do formacji katechetów, czego wyrazem było, między innymi erygowanie w 1978 roku Archidiecezjalnego Studium Katechetycznego. Szczególnie przychylny był katechetom świeckim, popierał ich inicjatywy, na przykład powstanie miesięcznika „Na Drogach Katechezy". Dzięki jego staraniom udało się otworzyć w Białymstoku Archidiecezjalne Kolegium Teologiczne i Studium Teologiczne.

Troszcząc się o zbawienie innych, doskonale wiedział, że najskuteczniejszym środkiem realizacji tej misji jest praca nad własnym uświęceniem. Świadczą o tym słowa osób, które go dobrze znały: „Był człowiekiem modlitwy i głębokiego życia duchowego" (kard. Henryk Gulbinowicz). Biskup Edward Ozorowski, który przez długie lata współpracował z bp. Kisielem, nazywa go „mistrzem życia wewnętrznego"; mówi o nim, że "prowadził wytrwałą pracę nad sobą"; wspomina pokorę, skromność i prostotę bp. Kisiela. Ksiądz Wacław Chilmon podkreślał natomiast obecność ofiary w jego życiu: „oddany sprawie Boga i Kościoła bez reszty, gotów do największych poświęceń".

Fakt, że w trudnych dla Kościoła czasach święci byli początkiem i źródłem odnowy, stał się dla bp. Kisiela podstawą do twierdzenia, że dla dobra

T. Krahel, Arcybiskup Edward Kisiel (1918-1993), [w:] T. Krahel (red.), Arcybiskup Edward Kisiel pierwszy Metropolita Białostocki, Białystok 1994, s. 9-47.

2 A. Kraszewska, Doskonałość chrześcijanina według nauczania biskupa Edwarda Kisiela, Warszawa 2006, s. 64 . 
wspólnoty Kościoła potrzeba przede wszystkim świętych katechetów. „Życzyłbym Archidiecezji Białostockiej i całemu Kościołowi gorliwych i świętych katechetów, zarówno duchownych, jak i świeckich" - mówił w jednym z wywiadów. Biskup wyjaśniał, co oznacza określenie „święty katecheta”: „to człowiek prowadzący intensywne życie wewnętrzne, którego owocem jest zgodność jego życia z tym, co głosi”. Biskup nazywał katechetę „pryzmatem, przez który przepływa światło Boże”. Mówił: „Jakże czysty i doskonały musi być pryzmat, żeby nie zniekształcał światła Bożego". Nauczał, że katecheza jest skuteczna, gdy jest poparta przykładem życia. Przytaczał słowa papieża Pawła VI, który mówił, że „człowiek chętniej słucha świadków, niż nauczycieli. Jeżeli zaś słucha nauczycieli, to ze względu na to, że są świadkami tego, co głoszą". Biskup jednoznacznie stwierdzał, że najistotniejszą sprawą w katechezie jest to, kim jest katecheta. Sprawę drugorzędną w nauczaniu, według biskupa, stanowią podręczniki, metody czy programy katechetyczne, chociaż nie bez znaczenia jest sposób, czy treść przekazu wiary. Zaznaczał też, że katecheta ma obowiązek dbać o własny rozwój intelektualny, ponieważ powinien być dobrze przygotowany do przekazywania Dobrej Nowiny. Katecheta ma być przede wszystkim święty.

Jak bp Kisiel rozumiał świętość? Przede wszystkim jako zjednoczenie z Chrystusem, które opiera się na głębokiej więzi z Nim. W budowaniu tej relacji podkreślał rolę łaski Bożej, którą katecheta i każdy wierzący otrzymuje poprzez sakramenty, modlitwę i rekolekcje. Biskup widział świętość jako doskonałość w miłości wobec Boga, z której wypływa miłość do ludzi; jako naśladowanie Chrystusa i jako pełnienie woli Bożej. Głosił, że niezbędnym elementem świętości jest pokora widziana jako prawda o Bogu i sobie samym.

\section{Zjednoczenie z Chrystusem i środki do jego osiągnięcia}

Biskup Edward Kisiel mówiąc o doskonałości człowieka podkreślał osobę Chrystusa. Chrześcijanin, który pragnie zjednoczenia z Nim i pozwoli Mu działać w swoim życiu, już nie sam pracuje nad uświęceniem, ale Chrystus czyni to w nim, zgodnie ze słowami św. Pawła: „Teraz zaś już nie ja żyję, lecz żyje we mnie Chrystus" (Ga 2, 20). Świętość staje się więc osobową i głęboką relacją z Chrystusem. Dobry katecheta to ten, który taką relację buduje. Staje się wtedy świadkiem, a nie tylko nauczycielem. Biskup nauczał, że katecheta ma promieniować wiarą, co oznacza, że inni patrząc na niego będą przekonani, że Chrystus jest dla niego najważniejszą osobą w życiu.

Do osiągnięcia głębokiej relacji z Chrystusem konieczna jest łaska, gdyż samo pragnienie zjednoczenia z Bogiem i wysiłek człowieka w tym kierunku, aczkolwiek niezbędne, nic nie znaczą bez łaski, zgodnie ze słowami: „Beze Mnie nic nie możecie uczynić" (J 15,5). Gdyby nie śmierć Jezusa i związane z nią odkupienie - nauczał Biskup - żaden człowiek nie mógłby być świętym. Łaska dla katechety jest potrzebna tak jak deszcz i słońce dla ziemi, by ta wydała plony. 
Biskup często podkreślał, że źródłem łaski jest Eucharystia, bez niej niemożliwe jest życie duchowe człowieka. Szczególnie katecheta, z racji tego, że naucza o Eucharystii, ma być człowiekiem Eucharystii. Biskup wyjaśniał, że owocne przeżywanie Mszy św. polega na oddawaniu samego siebie Chrystusowi. Chodzi o to, aby wszelkie ofiary, które człowiek nieustannie ponosi w życiu oddawać Bogu i łączyć z Jego ofiarą krzyżową. Uczestnictwo w ofierze eucharystycznej - nauczał - wymaga przygotowania wewnętrznego. To przygotowanie widział przede wszystkim w dbałości o czystość duszy, która powinna stać się nieustanną troską i pragnieniem człowieka.

Biskup Kisiel zachęcał do codziennego przyjmowania Chrystusa eucharystycznego. Nieporozumieniem - według niego - było to, gdy katecheta będąc na Mszy św. nie przystępuje do Komunii św. Wielokrotnie przypominał słowa samego Chrystusa: "Jeżeli nie będziecie jedli Ciała Syna Człowieczego, ani pili Krwi Jego, nie będziecie mieli życia w sobie" (J 6, 53). Stwierdzał za papieżem Piusem X, że „Komunia jest najkrótszą drogą do uświęcenia duszy”. Zaznaczał również, że Eucharystia nie jest nagrodą za dobre postępowanie, ale pomocą dla człowieka: „nie dla świętych, ale dla dążących do świętości” - mówił. Zachęcając do częstego przyjmowania Komunii św., podkreślał konieczność solidnego przygotowania się do niej i dziękczynienia za dar Eucharystii. Przygotowanie to widział nie tylko w stanie łaski uświęcającej, ale w oczekiwaniu na spotkanie z Chrystusem, w budzeniu w sobie wiary w Jego realną obecność w kawałku chleba. Uczestnictwo we Mszy św. oraz przyjęcie Komunii św. miało stawać się najważniejszym wydarzeniem dnia katechety. Biskup wskazywał też na adorację Najświętszego Sakramentu jako źródła łaski, nazywał ją „błogosławionym czasem" ze względu na to, że człowiek wiele może otrzymać od Chrystusa: „Przyjdźcie do Mnie wszyscy, którzy utrudzeni i obciążeni jesteście, a Ja was pokrzepię" (Mt 11, 28). Wskazywał, że pozostawanie Jezusa w tabernakulum jest darem, ale i zobowiązaniem, do tego, by przy Jezusie trwać. Wielu świętych podkreśla, że modlitwa jest najskuteczniejszym sposobem apostolstwa, więc warto, by zwłaszcza katecheta zachował właściwe proporcje między działaniem a modlitwą.

Modlitwa w nauczaniu bp. Kisiela ukazana jest nie tylko jako najlepszy środek apostolski, ale jako warunek konieczny do osiągnięcia głębokiej relacji z Jezusem. Przytaczał słowa ks. A. Słomkowskiego: „Nie wszyscy, którzy się modlili stali się świętymi, ale nikt nie stał się świętym, kto się nie modlił”. Konieczność modlitwy uzasadniał nakazem samego Chrystusa: "Czuwajcie i módlcie się” (Mt 26,41) oraz: „Wy zatem tak się módlcie...” (Mt 6, 8). Motywem podjęcia życia modlitwą powinien być również przykład Chrystusa, który modlił się nieustannie. To oznacza, że każdy chrześcijanin, a zwłaszcza katecheta powinien być człowiekiem modlitwy.

Kolejnym źródłem łaski jest sakrament pokuty. Biskup zachęcał do częstego korzystania z tego sakramentu, najlepiej co miesiąc. Mocno akcentował 
potrzebę dobrego przygotowania do tego sakramentu, do przeżywania go jako spotkania z Chrystusem w osobie kapłana. Zachęcał, żeby patrzeć na posługującego księdza jako na narzędzie w ręku miłosiernego Boga. Podkreślał zwłaszcza częsty, najlepiej codzienny, rachunek sumienia, gdyż daje on lepsze poznanie siebie, ułatwia pracę nad sobą i chroni od ciężkich upadków. Praktyka ta jest niezbędna dla katechety, jeżeli chce wzrastać w świętości. Posługiwał się porównaniem człowieka do okrętu: płynący statek nie zatonie, gdy załoga wylewa systematycznie niewielkie ilości wody jakie się przedostają na pokład oraz gdy zatyka szczeliny w burtach. Tak i człowiek nie zatraci się $\mathrm{w}$ złu, jeśli dostrzeże każdy grzech powszedni i będzie z nim walczył. Podkreślał, że nie chodziło tylko o grzechy dokonane czynem, ale również myślą, pożądaniem, słowem i zaniedbaniem dobra.

Biskup Kisiel podawał trzy warunki dobrej spowiedzi: zaufanie, szczerość i uległość. Ufać należy przede wszystkim Bogu, ale też kapłanowi jako jego zastępcy Chrystusa. Spowiedź często wywołuje niepokój, a nawet lęk. Jego sprawcą - zdaniem Biskupa - jest szatan, który stara się ją ukazać jako nieprzyjemne, wręcz nasycone lękiem przeżycie. Podkreślał potrzebę wiary katechety w miłosierdzie Boże, która ochroni go przed traktowaniem Boga jako groźnego sędziego. Pozwoli natomiast widzieć „Boga, który jest miłością”. Skupianie się wyłącznie na swych grzechach ukazywał jako poważny błąd. Dla potwierdzenia przypominał słowa proroka Izajasza: „Choćby wasze grzechy były jak szkarłat, jak śnieg wybieleją; choćby były czerwone jak purpura, staną się białe jak wełna" (Iz 1, 18).

Niezbędne w życiu katechety, jak i każdego wierzącego są dobrze odbyte rekolekcje. Biskup terminem "rekolekcje” określał czas odosobnienia od codzienności w celu skoncentrowania się na Bogu i własnej duszy, aby przemienić dotychczasowe życie. Nazywał też rekolekcje "czasem łaski” i do nich odnosił słowa św. Pawła: „Oto teraz czas upragniony, oto teraz dzień zbawienia” (2 Kor 6, 2).

Podawał warunki owocnego odprawienia rekolekcji. Pierwszym jest otwarcie na łaskę. Uzasadniając, podkreślał, że Bóg nie może nikogo bez jego woli obdarzyć łaską. Ponadto, człowiek otrzyma tyle łaski, ile zechce przyjąć. Wyjaśniał, porównując łaskę do wody czerpanej ze studni. Kto czerpie szklanką, będzie miał szklankę wody, kto wiadrem - wiadro. Te same rekolekcje mogą być przeżyte z różnym skutkiem przez różne osoby. Pomocą w otwarciu na łaskę rekolekcji - według Biskupa - jest pokorna modlitwa, w której człowiek nie licząc na samego siebie wszystkiego oczekuje od Boga. Prosić należy zwłaszcza o poznanie woli Bożej, o dobre natchnienia i postanowienia rekolekcyjne. Drugim warunkiem - według niego - jest praca nad sobą, która polega głównie na walce ze złem w sobie i postanowieniu poprawy. Podawał też szczegółowe wskazówki do pracy nad sobą w czasie rekolekcji, a więc: wzbudzenie intencji przeżywanych rekolekcji, troska o wyciszenie, stosowanie nauk rekolekcyjnych do życia. 
Zaznaczał, że treści rekolekcyjne katecheta powinien odnosić do siebie, a nie do innych, ponieważ jest to czas pracy nad sobą, a nie nad bliźnimi. Biskup podkreślał też trud pracy nad sobą, zwłaszcza trud przyjmowania bolesnej prawdy o sobie. Jest ona gorzka, jak lekarstwo - nauczał - ale skutecznie uzdrawia duszę. Jako trzeci warunek dobrego odprawienia rekolekcji wskazywał na samotność. Wyjaśniał, że nie tyle chodzi tu o samotność w sensie fizycznym, co raczej odosobnienie wewnętrzne. Konieczność odosobnienia uzasadnia słowami Chrystusa: „Pójdźcie wy sami osobno na pustkowie i wypocznijcie nieco” (Mk 6, 31). Wyjaśniał, że czas skupienia jest konieczny, gdyż inaczej człowiek nie podejmie głębszej refleksji nad istotą swego życia. Świat bowiem jest bardzo absorbujący, skłania do pośpiechu i aktywności, a „wielkie rzeczy dokonują się w ciszy". Czwartym warunkiem owocnych rekolekcji jest wielkoduszność, rozumiana przez biskupa jako ofiarne oddanie się Bogu do dyspozycji: "trzeba (...) oddać Bogu duszę, jak czystą kartę, niech sam na niej pisze, co zechce".

Wymieniał także korzyści płynące z rekolekcji: poznanie Boga oraz siebie samego, duchowe odnowienie, pokój wewnętrzny, przygotowanie do dobrej śmierci. Poznanie Boga zaowocuje wolnością od przywiązań do spraw ziemskich, a tym samym wolnością do pełnienia woli Bożej. Podkreślał konieczność odprawiania rekolekcji niezależnie od stopnia zaawansowania życia duchowego. Potrzebne są one zarówno grzesznikowi, który jest daleko od Boga, jak i sprawiedliwemu, który potrzebuje pobudzenia wiary i wzmocnienia sił duchowych. Potrzebne są każdemu katechecie.

\section{Doskonałość w miłości}

Biskup Edward Kisiel nauczając o świętości, jako zjednoczeniu osób, podkreślał rolę miłości. Nazywał ją istotą doskonałości. Mówił, że katecheta ma promieniować miłością, zwłaszcza wobec katechizowanych, okazywać im szacunek i zainteresowanie. Miłość - jego zdaniem - najpełniej wyraża się poprzez poświęcenie i ofiarę, stąd katecheta powinien być człowiekiem zdolnym do wyrzeczenia i oddania siebie. Powołując się na św. Augustyna nauczał o dwóch miłościach. Jedna to miłość własna, która gardzi Bogiem, druga to miłość do Boga posunięta aż do wzgardy siebie. W doskonałości chodzi właśnie o taką miłość, która Boga stawia na pierwszym miejscu, a zapomina o sobie. Jest ona możliwa jedynie w Bogu, gdyż On jest źródłem wszelkiej miłości (por. 1 J 4, 7. 10). Mówiąc o miłości jako istocie doskonałości przytaczał opowiadanie o bogatym młodzieńcu, który na pytanie, co ma czynić, aby osiągnąć życie wieczne otrzymał odpowiedź: „miłuj bliźniego swego, jak siebie samego” (Mt 19, 19). Przypominał też słowa św. Pawła, który w swym hymnie omawia, czym powinna charakteryzować się taka miłość (por. 1 Kor 13) oraz św. Jana, który stwierdza, że ,jeżeli miłujemy się wzajemnie Bóg trwa w nas, a miłość ku Niemu jest doskonała" (1 J 4,12). Rozwijając myśli zawarte w powyższych tekstach 
wskazywał, że Boga kocha ten, kto nie tylko wypowiada akty miłości, ale kto pełni Jego wolę i wykonuje swe obowiązki z motywów nadprzyrodzonych, co, ze względu na skażenie ludzkiej natury wymaga ofiary.

\section{Naśladowanie Chrystusa}

Doskonałość w wierze bp Kisiel rozumiał również jako naśladowanie Chrystusa. Uzasadniał to słowami samego Zbawiciela: „Jeśli kto chce pójść za Mną, niech się zaprze samego siebie, niech weźmie krzyż swój, i niech Mnie naśladuje” (Mt 16, 24) oraz „Kto nie bierze swego krzyża, a idzie za Mną, nie jest Mnie godzien" (Mt 10, 38). Naśladowanie Chrystusa polega na zaparciu się siebie, na rezygnacji z własnej woli na rzecz woli Bożej, innymi słowy na przyjęciu krzyża, który ofiarowuje Bóg. Krzyżem tym są przede wszystkim: ubóstwo, upokorzenia, choroby i wszelkie cierpienie. Krzyż, to również walka z własnymi pożądaniami i namiętnościami (por. Ga 5, 24). „Bez krzyża, cierpienia i ofiary nie ma świętości, bo nie ma heroizmu cnoty" - mówił. Naśladowanie Chrystusa to również życie w cichości i pokorze według słów: „uczcie się ode Mnie, bo jestem cichy i pokorny sercem" (Mt 11,28). Katecheta prowadząc innych do Chrystusa jako pierwszy ma iść za Jezusem.

\section{Pełnienie woli Bożej}

Katecheta ma być święty, a to oznacza otwartość na wolę Bożą. Chrystus nie tylko wzywał do posłuszeństwa Bogu, ale sam je okazywał, o czym świadczą słowa: „Wtedy rzekłem: „Oto idę - w zwoju księgi napisano o Mnie - aby spełnić wolę Twoją, Boże” (Hbr 10,5) oraz „Z nieba zstąpiłem nie po to, aby pełnić swoją wolę, ale wolę tego, który Mnie posłał"(J 6, 38). Potwierdza to też modlitwa Chrystusa w Ogrójcu, podczas której prosi On o oddalenie cierpienia, ale zgadza się na wolę Bożą (por. Mt 26, 39) i przyjmuje ją, czego wyrazem jest śmierć na krzyżu. Mówi o tym św. Paweł: „[Jezus] uniżył samego siebie, stając się posłusznym aż do śmierci -i to śmierci krzyżowej" (Flp 2, 8). Ponadto - uzasadniał bp Kisiel - po zapowiedzi męki przez Chrystusa, Szymon Piotr wyraził swój sprzeciw wobec cierpienia Jezusa. Chrystus surowo zganił Apostoła za postawę niezgody na wolę Bożą mówiąc: „Zejdź mi z oczu szatanie, bo nie myślisz po Bożemu, lecz po ludzku" (Mt 8, 33). Katecheta ma patrzeć na swoje życie, na katechizowanych, na wydarzenia $\mathrm{w}$ świetle wiary. To znaczy pamiętać, że Pan Bóg nawet z najtrudniejszych momentów życia wyprowadzi dobro, i że to, co po ludzku wydaje się klęską może być największym darem. Biskup proponował, by wcielać $w$ życie zasadę świętości, jaką praktykował św. Maksymilian Kolbe: $\mathrm{w}=\mathrm{W}$. Wyjaśnia, że „w” oznacza wolę człowieka, natomiast „W" - wolę Pana Boga, stąd wola człowieka ma zawsze zgadzać się z wolą Bożą. Potwierdza 
to słowami Chrystusa: „Jeśli Mnie kto miłuje, będzie zachowywał moją naukę, a Ojciec mój umiłuje go, i przyjdziemy do niego, i będziemy u niego przebywać" ( J 14, 23) oraz "Jeśli chcesz osiągnąć życie, zachowaj przykazania” (Mt 19, 16). Kolejnym tekstem biblijnym, który mówi o pełnieniu woli Bożej jako warunku osiągnięcia doskonałości są słowa: „Nie każdy, który Mi mówi: Panie, Panie! wejdzie do królestwa niebieskiego, lecz ten, kto spełnia wolę mojego Ojca, który jest w niebie" (Mt 7,21). Biskup przytaczał też naukę Jezusa z Kazania na Górze, który porównał człowieka słuchającego i wypełniającego słowo Boże do domu zbudowanego na skale. Taki człowiek oprze się wszelkim życiowym burzom. Ten, kto słucha, ale nie czyni, jest jak dom zbudowany na piasku, szybko ulegnie zniszczeniu (por. Mt 7, 24-27). Katecheta ma dom swojego życia budować na fundamencie Chrystusa. Tylko wtedy będzie w stanie owocnie przekazywać orędzie Zbawienia.

Podkreślał, że wola Boża jest wyrażona w 10 przykazaniach Bożych, stąd nie ma doskonałości bez przestrzegania Dekalogu. Jeśli człowiek uzna Boga za najwyższego i wszechmocnego Prawodawcę, to konsekwentnie przyjmuje Jego prawo. Posłuszeństwo przykazaniom umacnia z kolei więź człowieka z Bogiem. Życie według przykazań ukazywał jako trudne, ale możliwe do zrealizowania, gdyż jak mówi św. Paweł: „Wszystko mogę w tym, który mnie umacnia” (Flp 4, 13). Ponadto Bóg nigdy nie wymaga od człowieka więcej, niż ten może wykonać, więc nie należy popadać w zniechęcenie. Poza tym Chrystus obiecuje, że trud przeżywany razem z Nim staje się słodszy i lżejszy (por. Mt 11, 30).

Posłuszeństwo Bogu przez wypełnianie przykazań - podkreślał bp Kisiel - nie może być wymuszonym poddaniem się, gdyż celem przykazań nie jest pozbawienie człowieka wolności. Wręcz przeciwnie - brak zasad i nieograniczona swoboda prowadzą do zniewolenia. Przestrzeganie przykazań powinno wynikać z miłości, a nie przymusu. Uzasadniał to intencją Boga, jaką kierował się dając człowiekowi prawo. Ma ono służyć szczęściu wiecznemu, ale również doczesnemu wszystkich ludzi. Bóg stawia wysokie wymagania, ale obiecuje najwspanialszą nagrodę, jaką jest udział w Jego szczęściu. Prawo Boże jest bowiem drogowskazem w drodze do wieczności. Ponadto przykazania przynoszą błogosławieństwo i szczęście tym, którzy według nich postępują,

Stanem niepokojącym jest zjawisko oddzielenia wiary i moralności, które polega na deklaratywnym byciu chrześcijaninem przy jednoczesnym odrzucaniu praw moralnych. Niechęć do respektowania zasad Kościoła jest, według Biskupa, jednoznaczna z kwestionowaniem woli samego Stwórcy, gdyż Bóg mówi przez Kościół, stąd ważne jest, by katecheta wsłuchiwał się w głos Kościoła i był mu wierny. Podkreślał też, że święty katecheta powinien być wierny słowu Bożemu. Głosić ma nie siebie, nie swoją naukę, ale orędzie ewangeliczne, zgodnie ze słowami św. Pawła: „Nie głosimy bowiem siebie samych, lecz Chrystusa Jezusa jako Pana, a nas jako sługi wasze przez Jezusa” (2 Kor 4, 5). 


\section{Pokora}

Biskup Edward Kisiel podkreślał zasadniczą rolę pokory w drodze do doskonałości, która polega na otwieraniu człowieka na łaskę Bożą i prowadzi do wewnętrznej przemiany. Stwierdzał, że „nie ma świętości bez pokory”, ponieważ jest ona fundamentem życia wewnętrznego. Nie ma więc świętego katechety bez pokory. Skoro pokora jest fundamentem, to bez niej nie ma innych cnót. Stąd porównywał pokorę do łańcuszka w różańcu: jeśli usunie się go, wtedy wszystkie paciorki się rozsypią. Podobnie i cnoty nie istnieją bez pokory.

Pokora jest cnotą nadprzyrodzoną, która polega na uznaniu i umiłowaniu prawdy o sobie i o Bogu oraz na pragnieniu zapomnienia i wzgardy wobec samego siebie. Samo poznanie swej nędzy nie jest jeszcze cnotą, staje się nią dopiero umiłowanie tej prawdy. Taka postawa jest trudna do przyjęcia przez rozum i wolę ludzką, dlatego trzeba o nią prosić w modlitwie. Zwracał uwage na fałszywe rozumienie pokory i wyjaśniał, na czym ona nie polega. Pokora nie jest sztucznym uniżeniem przed ludźmi, niską oceną własnej wartości, ani niedołęstwem życiowym. Nie ma nic wspólnego z zewnętrzną postawą, marnym wyglądem, czy deklaracjami słownymi, ponieważ „nie jest pokornym, kto mówi, że jest pokornym".

Podstawową prawdą o człowieku jest fakt jego całkowitej zależności od Boga. Zależność tą Biskup oparł na dwóch faktach: stworzeniu człowieka przez Boga i dziedziczeniu grzechu pierworodnego. Uznanie tych dwóch faktów prowadzi tylko wtedy do pokory, gdy jest połączone z głęboką świadomością godności człowieka jako dziecka Bożego. Dla potwierdzenia tej tezy cytuje Psalm 8: „Czym jest człowiek, że o nim pamiętasz, i czym syn człowieczy, że się nim zajmujesz? Uczyniłeś go niewiele mniejszym od istot niebieskich chwałą i czcią go uwieńczyłeś. Obdarzyłeś go władzą nad dziełami rąk Twoich; złożyłeś wszystko pod jego stopy" (Ps 8, 5-7). Komentując ten fragment zwracał uwagę na fakt, że prawda o człowieku, to nie tylko jego grzeszność, ale również jego wielkość, która wynika ze stworzenia na obraz i podobieństwo Boże, zamieszkiwania Boga w człowieku, dziedziczenia Bożej chwały i uczestnictwa w Królestwie Chrystusowym. To wszystko jest darem udzielonym przez Boga w Jego niepojętej dobroci. Dopiero mając świadomość ogromnej wartości w oczach Bożych oraz ufając Jego miłości może człowiek przyjąć prawdę o własnej niemocy i grzeszności. Niemoc opisuje słowami Pisma Świętego i mówił, że tak, jak Bóg objawił siebie mówiąc: „Jestem, który Jestem” (Wj 3, 14), tak człowiek może powiedzieć o sobie: jestem, który nie jestem. Zaznaczał, że Bóg podtrzymuje człowieka w istnieniu i działaniu naturalnym oraz nadprzyrodzonym. Na płaszczyźnie naturalnej podkreślał słabość fizyczną i psychiczną człowieka, która przejawia się między innymi w chorobach i zranieniach. W sferze nadprzyrodzonej zwracał uwage na niemożność wykonania jakiegokolwiek dobra bez łaski, a nawet pragnienia owego dobra. Z owej niemocy, która jest skutkiem grzechu pierworodnego, wynika skłonność do grzechu. Czyni ona człowieka niewolnikiem miłości własnej 
i pożądliwości. Podkreślał, że skoro człowiek jest niewolnikiem grzechu, to bez łaski Bożej może uczynić jedynie grzech. Bóg jednak udziela łaski nieustannie i w ten sposób zachowuje człowieka od wielu upadków. Wynika stąd, że wszelkie dobro w życiu człowieka pochodzi od Boga.

Świadomość własnej słabości, a z drugiej strony łaskawości Boga sprawia, że katecheta i każdy wierzący przypisuje wszelką chwałę Bogu zgodnie ze słowami Maryi z Magnificat: „Wielbi dusza moja Pana (...). Bo wejrzał na uniżenie Służebnicy swojej” (Łk 1, 46-47). Postawa powyższa czyni człowieka zdolnym do wielkodusznego podejmowania trudnych nawet zadań z Bogiem i dla Boga.

Pokora, jak już powiedziano, to prawda o sobie samym i o Bogu. Pokorny katecheta nie będzie więc zaprzeczał darom, które otrzymał od Stwórcy, bo byłby to zdaniem bp. Kisiela fałsz. Aby nie stały się one jednak przyczyną wzrostu pychy, poleca nieustanną pamięć o ich Dawcy. Wzorem pokory ukazywanym przez Biskupa, jest Chrystus, który sam o sobie mówi: „Weźcie moje jarzmo na siebie i uczcie się ode Mnie, bo jestem cichy i pokornego serca” (Mt 11, 29). Innym tekstem, który według niego podkreśla uniżenie Chrystusa związane z Wcieleniem i Odkupieniem, są słowa św. Pawła:

On to istniejąc w postaci Bożej, nie skorzystał ze sposobności, aby na równi być z Bogiem, lecz ogołocił samego siebie, przyjąwszy postać sługi stając się podobnym do ludzi. A w zewnętrznej postaci, uznany za człowieka, uniżył samego siebie, stając się posłusznym aż do śmierci - i to śmierci krzyżowej (Flp 2, 6-8).

Biskup Kisiel mówiąc o pokorze Chrystusa podkreślał, że przez 30 lat prowadził On życie ukryte, a podczas działalności publicznej otaczał się zwyczajnymi ludźmi i nauczał w prosty sposób. Szczególnym wyrazem pokory Chrystusa - jego zdaniem - była zgoda na upokarzającą mękę oraz pozostanie w Eucharystii. Jednym z momentów, w którym Chrystus nie tylko okazał pokorę, ale też do niej wezwał była Ostatnia Wieczerza. Gest umycia nóg Apostołom był wyrazem Jego pokory i wskazaniem, że człowiek ma służyć, czyli zapominać o sobie, w myśl słów: „Syn Człowieczy nie przyszedł, aby Mu służono, lecz, aby służyć i dać swoje życie na okup za wielu" (Mt 20, 28). Biskup Kisiel ukazał powyższe teksty w celu wskazania drogi dla każdego człowieka, a szczególnie katechety; drogi, którą ma kroczyć do zjednoczenia z Bogiem. Innym przykładem pokory wobec Boga, jaki przedstawiał Biskup, jest postawa celnika z Ewangelii. Człowiek ów widząc swoje zło, przyznaje się do niego przed Bogiem i prosi o miłosierdzie: „Boże, miej litość dla mnie, grzesznika!” (Łk 18, 13). To on - zaznacza bp Kisiel - a nie faryzeusz odszedł usprawiedliwiony (por. Łk 18, 10-14). Podkreśla, że przepraszanie za zło i prośba o miłosierdzie są koniecznymi warunkami pokory i dokonują się poprzez modlitwę. Wzorem takiej modlitwy jest tekst: „O Jezu cichy i pokornego serca, uczyń serca nasze według serca Twego”, który nawiązuje do cytowanych już słów Jezusa (por. Mt 11, 29).

Biskup mówił też o pokorze w stosunku do ludzi, która, jak już wspomniano, polega na pragnieniu bycia wzgardzonym i chęci służenia. Stąd pokorny 
katecheta nie wywyższa się nad innych i nie chce być w centrum zainteresowania. Biskup oddaje to w słowach: „Choćbyś jak wielki był - uważaj się za najgorszego". Pokora wobec człowieka polega też na chętnym przyjmowaniu na siebie krzyża upokorzeń i odrzucenia przez bliźnich. Tak rozumianą pokorę uzasadniał dwoma tekstami Pisma Śrwiętego: „Lecz kto by między wami chciał stać się wielkim, niech będzie waszym sługą" (Mt 20, 26) oraz "Jeśli cię kto zaprosi na ucztę, nie zajmuj pierwszego miejsca" (Łk 14,8).

Biskup wyróżniał trzy stopnie pokory: 1. Nie wynosić się ponad innych, 2. Przyjmować chętnie upokorzenia, 3. Pragnąć upokorzeń. Podkreślał też, że człowiek za swe grzechy zasługuje na cięższe kary, niż upokorzenia, właściwie na wieczne potępienie. Tym samym powinien cierpliwie i z radością poddawać się krzyżowi, który go spotyka, w myśl słów: „Dobrze to dla mnie, że doznałem poniżenia" (Ps 119, 71). Za św. Janem od Krzyża biskup przypominał, że motywem przyjmowania przez człowieka upokorzeń ma być jedynie wola Boża.

Pokora jest darem Bożym, który wymaga współpracy ze strony katechety. Podstawowym środkiem wzrastania w pokorze jest modlitwa, gdyż jak mówił: „,jeden promyk łaski Bożej więcej ci w jednej chwili odsłonić może, niźli kilkuletnie rozmyślanie o pokorze". Polecał szczególnie zwracanie się do Serca Jezusa i do Matki Najświętszej. Cenną praktyką w oczach Biskupa było również rozważanie prawd o wielkości Boga oraz o uniżeniu Jezusa Chrystusa, a także stawanie przed Bogiem w prawdzie o sobie. Polega ono na przypominaniu własnych grzechów, uświadamianiu swojej nicości, a także porównywaniu siebie ze świętymi. Konieczną rzeczą jest też wykonywanie aktów pokory. Cnota, żeby stała się trwałą potrzebuje wielu ćwiczeń, które mogą polegać na przyjmowaniu upokorzeń, pogardzie wobec pochwał, wykonywaniu posług uważanych za poniżające oraz spokojnym przyjmowaniu wzgardy od innych. Podstawowym owocem pokory jest zjednoczenie z Bogiem, czyli osiągnięcie pełni doskonałości. Skutkiem praktykowania pokory jest też Boże błogosławieństwo, ponieważ Bóg pysznym sprzeciwia się, a obdarza swą łaską pokornych (por. Łk 1, 51-52). Błogosławieństwo to powoduje, że wysiłki zmierzające do wzrostu w pokorze zostaną nagrodzone. Biskup Kisiel uzasadniał to twierdzenie słowami Pisma Świętego: „Moją ofiarą, Boże, duch skruszony, nie gardzisz, Boże, sercem pokornym i skruszonym” (Ps 51,19) oraz „kto się poniża, będzie wywyższony” (Mt $23,12)$.

Biskup Edward Kisiel uważał przekaz wiary za jeden z podstawowych obowiązków Kościoła. Stąd poświęcał katechizacji bardzo dużo uwagi i sam angażował się w to dzieło. Wskazywał, że wiele czynników decyduje o skuteczności przekazu orędzia ewangelicznego, ale zasadniczym - jego zdaniem - jest osoba katechety: Najlepszym katechetą będzie święty katecheta. 


\section{Bibliografia}

Arcybiskup Edward Kisiel pierwszy Metropolita Białostocki, red. T. Krahel, Białystok 1994.

Bachurek A., Nauczanie pasterskie abp. E. Kisiela o kapłaństwie w wypowiedziach opublikowanych na łamach 'Wiadomosci Kościelnych' w latach 1976-1993, Warszawa 1997, mps w Archiwum Wydziału Katechetycznego w Białymstoku (dalej: AWKwB).

Górska H., Nauczanie pasterskie Abp. E. Kisiela o Miłosierdziu Bożym, Warszawa 1997, mps w AWKwB.

Hodun A., Święci archidiecezji wileńskiej w nauczaniu abp. E. Kisiela, Warszawa 1997, mps w AWKwB.

Ignatowicz A., Pasterz diecezji, „Wiadomości Kościelne Archidiecezji Białostockiej” 1993, nr 1, s. 30-40.

Jankowska A., Kościół w nauczaniu Abp. E. Kisiela, Warszawa 1997, mps w AWKwB.

Krahel T., Arcybiskup Edward Kisiel, metropolita białostocki, „Wiadomości Kościelne Archidiecezji Białostockiej" 1993, nr 1 , s. 4-10.

Krawczyńska G., Kult Matki Bożej w nauczaniu Abp. E. Kisiela, Warszawa 1997, mps w AWKwB.

Kraszewska A., Doskonałość chrześcijanina według nauczania biskupa Edwarda Kisiela, Warszawa 2006, mps w Bibliotece Uniwersytetu Kardynała Stefana Wyszyńskiego w Warszawie.

Krutul J., Problematyka rodzinna w nauczaniu Abp. E. Kisiela w latach 1976-1993, Warszawa 1995, mps w AWKwB.

Młyńska E., Ksiądz Arcybiskup Edward Kisiel jako katecheta, „Wiadomości Kościelne Archidiecezji Białostockiej" 1993, nr 1, s. 41-48.

Paniczko W., Wychowanie do trzeźwości w nauczaniu i działalności Abp. E. Kisiela, Warszawa 1997, mps w AWKwB.

Szczęsnowicz A., Problematyka oralna w nauczaniu pasterskim Arcybiskupa Edwarda Kisiela (1918-1993), Warszawa 2003, mps w Bibliotece Archidiecezjalnego Wyższego Seminarium Duchownego w Białymstoku.

Zimnoch K., Eucharystia w pasterskim nauczaniu Abp. E. Kisiela, Warszawa 1997, mps w AWKwB. 